\title{
In vivo survival rate of rabbit morulae after vitrification in a medium without serum protein
}

\author{
Jose-Salvator Vicente ${ }^{a *}$, Maria-Pilar Viudes-de-Castro ${ }^{\mathrm{b}}$, \\ Maria-Luz García ${ }^{a}$ \\ ${ }^{a}$ Biotechnology Reproduction Laboratory, Politechnical University of Valencia, \\ Camino de Vera, 14, 46071 Valencia, Spain \\ ${ }^{\mathrm{b}}$ Animal Production Division, EPSO, Miguel Hernández University, \\ Carretera de Beniel, 03312 Orihuela (Alicante), Spain
}

(Received 29 January 1999; accepted 12 July 1999)

\begin{abstract}
The in vivo survival rate of rabbit morulae after vitrification in a mixture of dimethyl sulphoxide and ethylene glycol solution without protein supplement (WPS) was compared with two types of protein supplements: rabbit serum (RS) and bovine serum albumin (BSA). Significant differences were observed in the percentage of transferable embryos (undamaged embryos after devitrification, $80.4 \%$ versus 93.2 and $92.1 \%$, WPS, BSA and RS, respectively, $P<0.05$ ) and live born rate $(40.9 \%$ versus $56.1 \%$, WPS and BSA, respectively, $P<0.05)$. Non-significant differences were, however, observed in the percentages of implanted embryos at 12 days post-ovulation induction $(56.7,69.7$ and $68.6 \%$ ), post-implantation survival rate $(82.3,74.2$ and $77.2 \%)$ and live born rate in pregnant does $(54.6,56.1$ and $50.5 \%$ ) with different vitrification media (RS, BSA and WPS). We conclude that rabbit embryos can be vitrified and stored using protein-free vitrification medium with moderate losses of viability. (C) Inra/Elsevier, Paris
\end{abstract}

rabbit embryos / vitrification / protein-free medium

Résumé - Taux de survie in vivo d'embryons de lapin au stade morula après vitrification dans une solution sans supplément protéique. Le taux de survie in vivo des embryons de lapins au stade morula après vitrification dans une solution de diméthylsulfoxide et éthylène glycol avec sérum de lapin, ou avec BSA ou sans supplémentation protéique a été étudié. On a observé des différences sur le taux d'embryons intact $(80,4 \%$ versus 92,1 et $93,2 \%$, sans supplément, avec sérum de lapin et avec BSA, $p<0,05)$ et sur le taux de viabilité d'embryons après vitrification $(40,9 \%$ versus $56,1 \%$ nés vivants, sans supplément protéique et BSA, respectivement, $p<0,05$ ). Il n'y a pas de différences pour le taux de viabilité post-implantation $(56,7,69,7$ and $68,6 \%$ ) et sur la viabilité dans les femelles receveuses gravides $(54,6,56,1$ and $50,5 \%)$ entre les trois milieux étudiés. En conséquence,

* Correspondence and reprints

E-mail: JVicent@dca.upv.es 
il est possible de vitrifier et de conserver des embryons de lapin en employant un milieu sans supplémentation protéique. (C) Inra/Elsevier, Paris

\section{morula / lapin / vitrification / milieu synthétique}

\section{INTRODUCTION}

Embryo cryopreservation has increased the mobility of genetic material in animal breeding; however, there is a risk of disease transmission through the donor animals (gametes or embryos) as well as through the environmental conditions to which the gametes or embryos are exposed. Generally, animal products such as sera and BSA are added to recovery, culture, cryopreservation or transfer media increasing the sanitary risk. Irradiation of commercial sera may reduce these risks, but some viruses can withstand even the effects of gamma radiation (BVD, for example). Replacement of serum by BSA certainly reduces the sanitary risks, but the safest way would be to employ substitutes for animal products [7].

The first studies of embryo freezing showed that adding serum appears to have a beneficial effect on the post-thaw survival of embryos $[1,2,23]$. As a consequence, permeating and non-permeating cryoprotectants in Dubelcco's phosphate-buffered saline, supplemented with either serum or bovine serum albumin, have been widely used for freezing or vitrification of embryos from livestock species [16].

Recently, non-organic macromolecules have been used as substitutes for serum supplements in cryopreservation media of mouse, ovine and bovine embryos without a significant loss of in vitro viability (polyvinyl alcohol in cattle [21]; hyaluronic acid in mouse and sheep [11]; ficoll in mouse [8]; and VF5, a block polymer of ethylene oxide and propylene oxide from pluronic group in cattle [17]).

In the cryopreservation of rabbit embryos, freezing or vitrification media have been supplemented with bovine serum albumin or bovine (calf or foetal) and rabbit sera (freezing: [14, 19, 23]; vitrification: $[12,18$, $22,24])$. Few studies have focused on the removal or substitution of sera in the cryopreservation media $[18,23])$. Tsunoda and Tsugie [23] observed the positive effect that rabbit serum had on the in vivo survival rate of frozen rabbit morulae and Papis et al. [18] demonstrated that rabbit morulae can survive in vitro after vitrification in a solution of glycerol and propylene glycol supplemented with bovine serum albumine (2-3 g. $\left.\mathrm{L}^{-1}\right)$.

The present study aims to evaluate the in vivo survival of rabbit morulae after vitrification in a mixture of dimethyl-sulphoxide and ethylene glycol solution with or without serum protein.

\section{MATERIALS AND METHODS}

\subsection{Experimental animals}

Multiparous does (4th-6th parities) of a rabbit synthetic strain (V) were used as embryo donors and recipients. This synthetic strain (V) was selected according to litter size at weaning over 21 generations. The strain and selection methodologies were described by Estany et al. [4].

\subsection{Embryo recovery}

Seventy-two donors were mated with bucks from the same strain and slaughtered $70-72 \mathrm{~h}$ post-coitum. The reproductive tract was then removed and the embryos were recovered by flushing with Dubelcco PBS (DPBS) at room temperature $\left(20-25^{\circ} \mathrm{C}\right)$. After recovery, morphologically normal embryos from three or four donor does were washed twice in fresh DPBS, pooled and kept at room temperature until use (10-15 min). 


\subsection{Vitrification media}

Three vitrification media were used. The cryoprotective solution had the following composition: $1: 1: 2(\mathrm{v} / \mathrm{v} / \mathrm{v})$ of dimethyl-sulphoxide (3.5 M DMSO, Sigma D5879), ethylene glycol (4.4 M EG, Sigma 9129) in PBS (D1283), and either without protein supplement or supplemented with one of the following two types of protein:

$-10 \%(\mathrm{v} / \mathrm{v})$ heat-inactivated rabbit serum (RS) obtained from the blood of donor does centrifuged at $3000 \mathrm{rpm}$ for $20 \mathrm{~min}$ and inactivated in a water bath at $56^{\circ} \mathrm{C}$ for $30 \mathrm{~min}$. This type of protein supplement had been used in previous studies $[6,24,25]$.

- 2 g BSA (Sigma, A3311) per litre of cryoprotective solution.

\subsection{Vitrification procedure}

Vitrification was carried out in two steps. First, normal embryos were pipetted into $0.2 \mathrm{~mL}$ of PBS medium and placed in a glass culture dish and then $0.2 \mathrm{~mL}$ of the cryoprotective solution in PBS (without protein supplement - WPS, supplemented with RS or BSA) was added and shaken. The embryos were left in this medium for $2 \mathrm{~min}$. In the second step, $0.6 \mathrm{~mL}$ of the cryoprotective solution in PBS (without protein supplement - WPS, supplemented with RS or BSA) was added and shaken quickly. Then, the embryos suspended in the final vitrification solution (2.8 M DMSO and 3.5 M EG in PBS with or without protein supplement) were loaded into $0.25-\mathrm{mL}$ plastic straws (IMV, L'Aigle, France) and plunged directly into liquid nitrogen. The exposure time of embryos to the final vitrification solution did not exceed $1 \mathrm{~min}$. The two vitrification steps were carried out at $20^{\circ} \mathrm{C}$.

The straws contained three sections separated by air bubbles. The first consisted of PBS in the cotton plug, the second of embryos suspended in the vitrification medium $(0.1 \mathrm{~mL})$ and placed in the middle of the fraction. The third section consisted of PBS. The straws were sealed with coloured plastic. Each straw held between nine and twelve normal morulae from three to four donor does. The embryos were stored in liquid nitrogen for 1-9 months.

Devitrification was performed by immersing the second and third sections of the straws in a water bath at $20^{\circ} \mathrm{C}$ for $10-15 \mathrm{~s}$. The cryoprotective solution was removed from the embryos in a two-step dilution procedure at room temperature $\left(20-25^{\circ} \mathrm{C}\right)$. The embryos suspended in the final vitrification solution $(0.1 \mathrm{~mL})$ were released into a glass dish containing $1 \mathrm{~mL}$ of $0.33 \mathrm{M}$ sucrose in PBS medium. After $2 \mathrm{~min}$, the embryos were washed twice in fresh PBS medium and scored morphologically before transfer. Only embryos with a homogeneous cell mass and an intact zona pellucida were transferred.

\subsection{Embryo transfer}

Fifty-two recipient does were used. All recipient does were multiparous does in the second week of lactation. Ovulation was induced in receptive recipient does with an intramuscular dose of $0.8 \mathrm{mg}$ buseriline acetate (Hoescht) $60-64 \mathrm{~h}$ before transfer. Only does with red vulvar lips were synchronised.

The recipients were anaesthetised by injecting a solution of ketamine at the rate of $1.2 \mathrm{~mL} \cdot \mathrm{kg}^{-1}$ body weight. Oviductal transfer in lactating does was carried out according to the procedure described by García-Ximénez and Vicente [5]. Oviductal embryo transfer was performed unilaterally. Seven to twelve normal embryos were transferred to each recipient doe.

\subsection{Assesement of in vivo viability}

The in vivo survival rate was evaluated 10 days post-transfer and at birth. Laparoscopy was carried out 10 days post-transfer in 30 pregnant recipient does to compare the percentage of implanted embryos and the losses at birth between treatments. The laparoscopic technique used was described by Molina [15] and Santacreu et al. [20].

\subsection{Statistical analysis}

A Chi-squared test was used to analyse the percentages of transferable embryos (non-damaged embryos after thawing/vitrified embryos) and implanted embryos (implanted/transferred embryos), and rates of pregnancy, born alive (born alive/transferred embryos) and post-implantation survival (born alive/implanted embryos) between vitrification media. 


\section{RESULTS}

Four-hundred and fifty-four $(88.8 \%$, table I) out of 511 vitrified embryos were transferable embryos. Significant differences were found in transferable embryos between vitrification media ( $80.4 \%$ versus 92.1 and $93.2 \%$, WPS, RS and BSA, respectively, $P<0.05$, table I).

Forty-eight $(92 \%)$ of the 52 transferred recipients, became pregnant $(94,100$ and $81 \%$ RS, BSA and WPS, respectively, table $I$ ). The live born rate from the vitrification medium supplemented with BSA was higher than the corresponding itrification mediuma without protein $(56.1 \%$ versus $40.9 \%, P<0.05$, respectively, table $I$ ). The live born rates of pregnant recipients were, however, similar (54.6, 56.1 and 50.5\%, RS, BSA and WPS, respectively, data not shown in tables). Among the rabbit serumvitrification medium treatment group two were stillborn and in the vitrification medium without protein supplement one was stillborn.

In the 30 pregnant recipient does examined by laparoscopy at 10 days post-transfer, no significant differences were observed in the percentage of implanted embryos (56.7, 69.7 and $68.6 \%$, RS, BSA and WPS, respectively, table II) nor in the post-implantation survival rate for the different vitrification media (82.3, 74.2 and $77.2 \%$ RS, BSA and WPS, respectively, table II).

\section{DISCUSSION}

In order to establish an embryo bank for preserving genetic resources and facilitate the exchange of embryos of specific genotypes, it may be necessary to eliminate animal proteins from cryopreservation media in order to reduce the possibility of disease transmission.

In the freezing of rabbit embryos, however, Tsunoda and Sugie [23] demonstrated that the in vivo survival rate ( $49 \%$ versus $14 \%$ ) was improved by adding $50 \%$ of rabbit serum to the freezing medium. Kojima et al. [13] suggested that the addition of serum to the freezing medium masks the question of the cryoprotection mechanisms, because the protective effects of serum could potentially be exerted not only during the cooling and warming processes but also during the period immediately after thawing. Serum

Table I. Survival rate at birth of morulae vitrified in media without (WPS) or with protein supplement (rabbit serum - RS, or bovine serum albumin - BSA).

\begin{tabular}{llllll}
\hline Group & No. straws & $\begin{array}{l}\text { Vitrified } \\
\text { embryos }\end{array}$ & $\begin{array}{l}\text { Transferable } \\
\text { embryos }(\%)\end{array}$ & $\begin{array}{l}\text { Pregnant does } \\
(\%)\end{array}$ & $\begin{array}{l}\text { Born alive } \\
(\%)\end{array}$ \\
\hline RS & 18 & 177 & $\begin{array}{l}163 \\
(92.1)^{\mathrm{a}}\end{array}$ & $\begin{array}{l}17 / 18 \\
(94.4)\end{array}$ & $\begin{array}{l}83 \\
(50.9)^{\mathrm{ab}}\end{array}$ \\
BSA & 18 & 176 & 164 & $18 / 18$ & 92 \\
& & & $(93.2)^{\mathrm{a}}$ & $(100.0)$ & $(56.1)^{\mathrm{a}}$ \\
WPS & 16 & 158 & 127 & $13 / 16$ & 52 \\
& & & $(80.4)^{\mathrm{b}}$ & $(81.3)$ & $(40.9)^{\mathrm{b}}$ \\
Total & 52 & 511 & 454 & $48 / 52$ & 225 \\
& & & $(88.8)$ & $(92.3)$ & $(49.6)$ \\
\hline
\end{tabular}

Transferable embryos $(\%)$ : (non-damaged embryos/vitrified embryos) $\times 100$.

Born alive (\%): (alive born alive/transferable embryos) $\times 100$. 
Table II. Post-implantation survival of morulae vitrified in media without or with protein supplement (rabbit serum - RS, or bovine serum albumin - BSA).

\begin{tabular}{|c|c|c|c|c|c|}
\hline Group & $\begin{array}{l}\text { Recipient } \\
\text { does }\end{array}$ & $\begin{array}{l}\text { Transferred } \\
\text { embryos }\end{array}$ & $\begin{array}{l}\text { Implanted } \\
\text { embryos (\%) }\end{array}$ & $\begin{array}{l}\text { Born alive } \\
(\%)\end{array}$ & $\begin{array}{l}\text { Post-implantation } \\
\text { survival rate }\end{array}$ \\
\hline RS & 10 & 90 & $\begin{array}{l}51 \\
(56.7)\end{array}$ & $\begin{array}{l}42 \\
(46.7)\end{array}$ & 82.3 \\
\hline BSA & 10 & 89 & $\begin{array}{l}62 \\
(69.7)\end{array}$ & $\begin{array}{l}46 \\
(51.6)\end{array}$ & 74.2 \\
\hline WPS & 10 & 83 & $\begin{array}{l}57 \\
(68.6)\end{array}$ & $\begin{array}{l}44 \\
(53.0)\end{array}$ & 77.2 \\
\hline Total & 30 & 264 & $\begin{array}{l}170 \\
(64.4)\end{array}$ & $\begin{array}{l}132 \\
(50.0)\end{array}$ & 77.6 \\
\hline
\end{tabular}

Post-implantation survival rate: (born alive/embryos observed to be implanted 10 days post-transfer) $\times 100$. Born alive: (born alive/transferred embryos in recipient does) $\times 100$.

may increase cellular stability by providing protein or repairing damaged membranes by including fatty acids and lipid components. The results obtained in the present work suggest that in this vitrification procedure, the effects of serum or BSA supplements had a protective effect on physical damage and overall survival rate of the embryos. When we analysed the data on pregnant recipients, however, the live born and post-implantation survival rates were similar for each type of vitrification media. Surfactant properties of vitrification media with protein (serum or BSA) probably suppressed or reduced ice formation during the heating process used.

In addition, this study demonstrated that successful vitrification of rabbit embryos can be achieved using BSA to substitute rabbit serum supplementation reducing the sanitary risk. The in vivo survival rate observed was comparable to that obtained by Smorag and Gajda [22], Kasai et al. [12] or Vicente and García-Ximénez, [24, 25] using calf or rabbit serum. Papis et al. [18], however, used BSA ( $\left.3 \mathrm{mg} \cdot \mathrm{mL}^{-1}\right)$ in a vitrification medium containing $2.72 \mathrm{M} 1,2$ propanediol and $1.36 \mathrm{M}$ glycerol and obtained a high in vitro survival rate (80-89\%), but only a $6.7 \%$ in vivo survival rate. In other species, Ishimori et al. $[9,10]$ demonstrated the efficacy of a vitrification mixture of ethylene glycol and dimethyl sulphoxide supplemented with BSA to cryopreserve mouse and bovine embryos (49 and $39 \%$ live foetuses, respectively).

Data obtained for the post-implantation survival $(77.6 \%)$ of vitrified embryos did not, however, differ from those observed in non-transferred does by Molina [15], Santacreu et al. [20], Viudes de Castro et al. [26] and Blasco et al. [3] using the source rabbit line as that used in the present study. The damage caused by cryopreservation did not appear to have any negative effects on the post-implantation development of rabbit foetuses post-implantation.

In order to establish a rabbit embryo bank with a reduced risk of disease transmission, vitrification in a medium without serum protein can be used with a moderate in vivo survival rate $(50.5 \%$ in pregnant recipients). Further studies might focus on adding nonorganic macromolecules to vitrification media to reduce the physical damage of embryos. 


\section{ACKNOWLEDGEMENT}

This study was supported by European Project RESGEN1-CT95-0060 and CICYT Project AGF97-0803.

\section{REFERENCES}

[1] Bilton R.J., Moore N.W., Effects of ice seeding and of freezing and thawing rate on the development of sheep embryos stored at minus $196^{\circ} \mathrm{C}$, Theriogenology 6 (1976) 635.

[2] Bilton R.J., Moore N.W., In vitro culture, storage and transfer goat embryos, Aust. J. Biol. Sci. 20 (1976) 125-129.

[3] Blasco A., Santacreu M.A., Argente M.J., Genetic parameters of ovulation rate, embryo and fetal survival in rabbits, J. Appl. Rabbit Res. 15 (1992) 247-254.

[4] Estany J., Baselga M., Blasco A., Camacho J., Mixed model methodology for estimation of genetic response to selection in litter size in rabbits, Livest. Prod. Sci. 21 (1988) 67-75.

[5] García-Ximénez F., Vicente J.S., Oviductal embryo transfer in lactating does by laparotomy, in: Dziuk P., Wheeler M. (Eds.), Handbook of Methods for Study of Reproductive Physiology in Domestic Animals, University of Illinois, 1991.

[6] García-Ximénez F., Vicente J.S., Cifre J., Baselga M., Foundation of a maternal rabbit line using hysterectomy and embryo cryopreservation, VI World Rabbit Congress, Toulouse, 1996, pp. 285-288.

[7] Guerin B., Nibart M., Marquant-Le Guienne B., Humblot P., Sanitary risks related to embryo transfer in domestic species, Theriogenology 47 (1997) 33-42.

[8] Gutiérrez A., Garde J., Artiga C.G., Muñoz I., Pintao B., In vitro survival of murine morulae after quick freezing in the presence of chemically defined macromolecules and different cryoprotectants, Theriogenology 39 (1993) 1111-1120.

[9] Ishimori H., Takahashi Y., Kanagawa H., Viability of vitrified mouse embryos using various cryoprotectant mixtures, Theriogenology 37 (1992) 481-487.

[10] Ishimori H., Saeki K., Insi M., Nagao Y., Itsaka J., Miki N., Seike N., Kainuma H., Vitrification of bovine embryos in a mixture of ethylene glycol and dimethyl sulfoxide, Theriogenology 40 (1993) 427-433.

[11] Joly T., Nibart M., Thibier M., Hyaluronic acid as substitute for proteins in the deep freezing embryos from mice and sheep: an in vitro investigation, Theriogenology 37 (1992) 473-480.
[12] Kasai H., Hamaguchi Y., Zhu S.E., Miyake T., Sakurai T., Machida T., High survival of rabbit morulae after vitrification in a ethylene glycol-based solution by a simple method, J. Reprod. Fertil. 89 (1992) 91-97.

[13] Kojima T., Soma T., Oguri N., Effect of rapid addition and dilution of dimethylsulfoxide on the viability of frozen-thawed rabbit morulae, Cryobiology 22 (1985) 409-416.

[14] Maurer R.R., Haseman J.K., Freezing morula stage rabbit embryos, Biol. Reprod. 14 (1976) 256-263.

[15] Molina I., Determinación de los efectos genéticos directos y maternos sobre la tasa de ovulación y la viabilidad embrionaria y fetal en el conejo, mediante aplicación de las técnicas de transferencia de embriones y laparoscopí, thesis, Universidad Politécnica de Valencia, 1987.

[16] Niemann H., Cryopreservation of ova and embryos from livestock: Current status and research needs, Theriogenology 35 (1991) 109-124.

[17] Palasz A.T., Tornesi M.B., Archer J., Mapletof R.J., Media alternatives for the collection, culture and freezing of mouse and cattle embryos, Theriogenology 44 (1995) 705-714.

[18] Papis K., Fujikawa S., Kojima T., Oguri N., Effect of the composition of vitrification media on survival of rabbit embryos, Cryobiology 30 (1993) 98-105.

[19] Renard J., Garnier V., Parvex R., Production et congélation de l'embryon de lapin, $3^{\text {es Journées }}$ de la Recherche Cunicole, Paris, communiction $\mathrm{n}^{\circ} 18,1982$.

[20] Santacreu M.A., Viudes-De-Castro M.P., Blasco A. Évaluation par coelioscopie des corps jaunes et des embryons et influence de cette technique sur la taille de portée, Reprod. Nutr. Dev. 30 (1990) 583-588.

[21] Seidel G.E. Jr, Elsden R.P., Brink Z., Cryopreservation of bovine embryos in media with chemically defined macromolecules, Theriogenology 33 (1990) 322

[22] Smorag Z., Gajda B., Vitrification of non-cultured and cultured rabbit embryos, Anim. Reprod. Sci. 26 (1991) 151-158.

[23] Tsunoda Y., Sugie T., Effect of freezing medium on the survival of rabbit eggs after deep freezing, J. Reprod. Fert. 50 (1977) 123-124.

[24] Vicente J.S., García-Ximénez F., Osmotic and cryoprotective effects of a mixture of DMSO and ethylene glycol on rabbit morulae, Theriogenology 42 (1994) 1205-1215.

[25] Vicente J.S., García-Ximénez F., Direct transfer of vitrified rabbit embryos, Theriogenology 45 (1996) 811-815.

[26] Viudes de Castro M.P., Santacreu M.A., Vicente J.S., Effet de la concentration énergétique de l'alimentation sur les pertes embryonnaires et fotales chez la lapine, Reprod. Nutr. Dev. 31 (1991) 529-534. 